\title{
Relative Income and Attitudes towards Long-Term Care Financing
}

\author{
Joan Costa-Font $^{\mathrm{a}}$, Anna Garcia-Gonzalez ${ }^{\mathrm{b}}$ and Montserrat Font-Vilalta ${ }^{\mathrm{c}}$ \\ ${ }^{a}$ European Institute \& LSE Health, London School of Economics, Cowdray House, Houghton Street, \\ London WC2A 2AE, U.K. \\ E-mail: j.costa-font@1se.ac.uk \\ ${ }^{\mathrm{b}}$ CAEPS, University of Barcelona, Diagonal 690 Catalonia, Barcelona 08034, Spain. \\ E-mail: anagarciagonzalez@ub.edu \\ ${ }^{\mathrm{c}}$ Universitat de Barcelona, Barcelona, Catalonia, Spain. \\ E-mail: montsefont@ub.edu
}

Understanding economic motivations underlying attitudes towards long-term care (LTC) financing alternatives is important for both public and private insurance design. This paper empirically explores for the first time, using survey data, the empirical validity of individual absolute and relative income (affluence) as explaining attitudes towards the financing of LTC in Spain in 2002, after controlling for professional, institutional and personal characteristics. We find that more affluent individuals prove to be less likely to support state responsibility for LTC after controlling for other institutional determinants and are less enthusiastic about social insurance. While attitudes towards state responsibility are negatively associated with relative income, attitudes towards social insurance and other funding alternatives are found to be driven by absolute income. Finally, evidence suggests that income-related attitudes appear to concentrate in the age group close to retirement who arguably have already saved for old age needs.

The Geneva Papers (2008) 33, 673-693. doi:10.1057/gpp.2008.32

Keywords: attitudes; relative income; long-term care financing; state responsibility

\section{Introduction}

Most European countries are in the process of reviewing their institutional design for insuring and delivering long-term care (LTC). ${ }^{1,2}$ Generally speaking, LTC refers to non-medical sources of care, including nursing, personal and social care, and domestic help. ${ }^{3}$ Traditionally, before the advent of public (and private) insurance agencies, LTC services were delivered and financed through intergenerational transactions within households. However, new patterns of social and demographic change have put in question the role of the family as the last resort provider and have created a demand for the development of both public and private insurance schemes.

\footnotetext{
${ }^{1}$ LTC refers to a wide variety of paid and unpaid services provided to dependent individuals, who are people who need assistance as a result of a mental or physical disability or a chronic illness. It involves personal care to help with activities of daily living such as bathing, eating, getting into bed or with the activities necessary for leading an independent life, called instrumental activities of daily living, which include shopping, cooking or taking medication.

${ }^{2}$ Costa-Font et al. (2008).

${ }^{3}$ Glendinning et al. (2004).
} 
Given that public LTC insurance, unlike private alternatives, has both risk pooling and redistributive goals, reforms that attempt to set up limits to state involvement in LTC financing are controversial due to its distributional implications. ${ }^{4}$ Public support for different forms of public involvement is likely to be motivated by individuals' support for (or against) redistribution-enhancing LTC insurance designs, which is likely to depend on their expected benefits. However, limited knowledge has been reported on the role of individuals' affluence - as proxing lesser benefits from redistribution programmes - on support for and attitudes towards the role of the state in LTC insurance design. The importance of understanding attitudes is made clear by the German case, where the integration of LTC insurance into the general socialsecurity system was justified by public support. ${ }^{5}$ On the other hand, examining people's attitudes is an important endeavour on its own if individuals' choice is driven by normative preferences ${ }^{6}$ that people determine beforehand and then follow in their consumption decisions, or if individuals follow the so-called theory of planned behaviour. ${ }^{7}$ However, perhaps for their strategic and distributional implications, individual attitudes are hypothesised to express some form of actual self-interest.

Attitudes towards the welfare state appear to be anchored in an individual's income. Indeed, some studies find that preferences for redistribution are explained by selfinterest along with values and beliefs. ${ }^{8}$ However, the specific reference points individuals take into consideration in assessing the distributional implications of their attitudes are not known. Following this intuition, individuals' affluence can influence their attitudes in two ways. First, richer individuals (in absolute terms) tend to be less likely to support distributive financing alternatives (e.g., social insurance) although not necessarily state involvement. Similarly, if preferences for redistribution (through public financing) are locally formed, it might well be that it is relative income to that of their community, namely that local affluence explains attitudes. The latter would be consistent with evidence suggesting that individuals whose income lies below the mean level of income of their community would be more likely to support redistribution efforts. ${ }^{9}$ This expectation draws upon findings from the happiness literature and has shown that individuals evaluate their well-being relative to others in their reference group. ${ }^{10}$

This paper aims to examine whether attitudes towards LTC financing are explained (anchored in) by relative and absolute income after controlling for institutional and socio-economic controls. Drawing from 2002 survey data from Spain - a country that has only recently introduced a public programme to cover LTC financing that will, however, not be fully operative until 2015 - we test whether affluent individuals - both

\footnotetext{
${ }^{4}$ In most European countries, public intervention has not attempted to replace individual responsibility completely, and public intervention relies on intergenerational equity with some cross-country differences in the extent of cost sharing.

${ }^{5}$ Geraedts et al. (2000).

${ }^{6}$ Beshears et al. (2008).

7 Ajzen (1991).

${ }^{8}$ Fong (2001).

${ }^{9}$ Meltzer and Richard (1981).

${ }^{10}$ Ferrer-i-Carbonell (2004); Clark and Oswald (1996); Clark et al. (2006).
} 
absolute and relative to their local community - exhibit a different attitude towards the financing and delivering of LTC services. We attempt to better understand what motivated public support to limit state involvement in LTC financing in Spain. We empirically examine whether more (less) absolute and relatively affluent individuals are less (more) likely to support state coverage of LTC (Research Question One (RQ1)). Second, we test whether higher absolute and relative income explains attitudes towards redistributive options of LTC financing, namely social insurance (RQ2). Alternative financing instruments such as company support or tax relief for people to provide care to the elderly are examined, as they are expected to be influenced by an individual's capacity to pay.

The relevance of researching this question using Spanish data lies in that along with other Southern European countries, LTC reform in Spain has been a matter of recent concern. ${ }^{11,12}$ Traditionally, solutions to the social-coordination problems of providing and paying for LTC have been provided by families, and only those struggling for immediate support have been helped by the state, as a last resort. ${ }^{13}$ However, the question of whether attitudes towards LTC are motivated by individuals' both absolute and relative income has not been previously researched to the best of our knowledge both in Spain and elsewhere. ${ }^{14}$

We control for institutional constraints, demographics along with socio-economics characteristics and professional activity. Age-specific interactions are examined to identify potential sources of self-interest, motivated by having sorted alternative funding for LTC, or instead by expecting to free ride from future generations. The importance of professional activity lies in that state funding and provision may arguably provide mechanisms for corporate self-interest and, to some extent, freeriding by civil servants. Indeed, civil servants have traditionally enjoyed a privileged position due to their knowledge of what is covered by the system and their reliance on the public sector for income purposes. Ideology may also affect attitudes to LTC; people who uphold left-wing ideological values are probably more likely to approve of state provision for LTC. However, given that it can be to a large extent endogenous, we control for the political environment, measured by regional left-wing party support. An individual's age, education and gender might influence individuals experience with LTC needs and the demand for redistribution.

The paper is organised as follows. The next section contains the study background. The subsequent section deals with data and methods. The penultimate section reports the results and the final section the conclusions.

${ }^{11}$ Costa-Font and Font-Vilalta (2006, 2008).

${ }^{12}$ Many reforms of the LTC system took place in the late 1990s, at a time when social spending on elderly people as a percentage of GDP declined or ceased to increase, especially in Scandinavian countries and the English-speaking world, while the real benefits for old people continued to grow (Castles, 2005).

${ }^{13}$ Social expenditure in Spain has remained constant over the last few decades at about 20 per cent of GDP (Castles, 2005; OECD, 2004), slightly below other Southern European countries such as Italy and Greece, but above Portugal.

${ }^{14}$ Some evidence suggests that even though people's perceptions of risks explains the likelihood of people being willing to pay for LTC insurance in Spain (Costa-Font and Rovira, 2008), myopia does not seem to stand out as an empirical explanation for lack of insurance mechanisms. 


\section{Background}

\section{Affluence and attitudes}

We conceptualise attitudes as behavioural positions (judgements) towards an object of interest ${ }^{15}$ based on the limited information on hand. Economic theory might well conceptualise them as normative preferences, which are argued to determine or constrain further individual behaviour (revealed preference). ${ }^{16}$ Indeed, take the example of access to a nursing home when dependent; some evidence has shown that favourable attitudes to nursing home services increased the odds of subsequent use by 1.5. ${ }^{17}$ In recent economic literature, attitudes are understood as expressions of a latent demand for collectively financed goods, ${ }^{18}$ especially in the absence of real market data. This happened in the LTC arena during the discussions at the Royal Commission on LTC in England on how best to finance LTC. ${ }^{19}$ However, it still remains an important question how to interpret evidence on attitudes and, particularly, to disentangle whether they convey an expression of true rational preferences based on an expectation of how the introduction of a financing instrument to pay for LTC will affect affluence. Currently, most countries have some forms of means testing and cost sharing to monitor the demand for LTC services. Yet, one of the unintended effects of means-testing arrangements is that middle-class and higher-income groups may be left to look after themselves. ${ }^{20}$ Therefore, hypothetically, attitudes towards LTC financing alternatives can be envisaged as rational strategic responses to institutional design reflecting the individuals' best interest.

An empirical test to scrutinise whether individuals appear to make cost-benefit calculations that would be expressed in their attitudes lies in examining whether the individuals' income, both absolute and/or relative to a reference group, seems to be driving their attitudes (especially at different age groups). In other words, by computing income elasticities of attitudes it is possible to ascertain the extent to which attitudes are anchored in the individuals' absolute or relative income or, alternatively whether other underlying effects are guiding latent individual support for different forms of LTC provision and financing. Whether income anchoring prevails in forming attitudes is far from straightforward on the basis of previous literature. Indeed, evidence on public-spending attitudes in the U.K. reveals a weak association between support for spending increases on certain public programmes and household income. ${ }^{21}$ It is argued that this is due to the fact that richer individuals benefit from some forms of public expenditure. On the other hand, people would be expected to prefer the public goods that benefit them the most and for which the financial burden weighs less

\footnotetext{
15 Ajzen (1991).

${ }^{16}$ Beshears et al. (2008).

${ }^{17}$ Rabiner (1996).

${ }^{18}$ Preston and Ridge (1995).

${ }^{19}$ However, some limitations must be taken into account, namely the extent to which attitudes reveal stable preferences, and some controls are required, such as providing dummy answers in case people are unwilling to think about their own potential for LTC.

${ }^{20}$ Laing (1993).

${ }^{21}$ Hall and Preston (1999).
} 
heavily on them, especially if they can foresee a tax increase. ${ }^{22}$ Some evidence shows that attitudes tend to reflect people's socio-economic position. ${ }^{23}$ Evidence of the role of attitudes in the area of old age welfare (attitudes towards taxes for social security in the United States) indicates that perceived benefits are shaped largely by self-interest, rather than by partisanship and ideology. ${ }^{24}$ However, self-interested motivations might well overshadow people's endorsement of institutions and policies that are socially desirable and that already exist, as they encompass a given set of shared values. ${ }^{25}$ Thus, social insurance systems would hypothetically be supported by the middle classes as an alternative to a means-tested programme. In European countries, it has been recognised that the feasibility of LTC funding depends on people's attachment to the system of public funding. ${ }^{26}$

\section{Empirical evidence}

General evidence from Eurobarometer-type data for all European countries suggests that most Europeans opted for state involvement. ${ }^{27}$ The figures varied from 80 per cent in Sweden to 36 per cent in Spain. However, in Austria 41 per cent of respondents stated that their children should be responsible for LTC, Spain ranked second on this issue (30 per cent) followed by Portugal ( 29 per cent), Greece ( 27 per cent) and Italy (23 per cent).

At a country level, evidence from the U.K. indicates a consistent and robust public option for state funding for LTC. ${ }^{28}$ According to findings by Parker and Clarke, ${ }^{29}$ respondents expected LTC to be a public responsibility irrespective of age, socioeconomic position and political preference. Indeed, 89 per cent agreed that "the state should be responsible for providing care for elderly people, although 48 per cent agreed that 'the state should pay for basic services, and people who can afford it should be able to pay for better care". Parker and Clarke ${ }^{30}$ found that only 6 per cent of respondents said they would purchase LTC insurance. On the other hand, there was very little support for compulsory insurance even when paid for at work ( 24 per cent), although 78 per cent felt that people should be able to buy insurance if they wished. Attitudes to public funding were less supportive among respondents who owned property. ${ }^{31}$ Finally, qualitative evidence from Britain indicates that in general people lacked correct information and were dissatisfied with the way the system worked. ${ }^{32}$

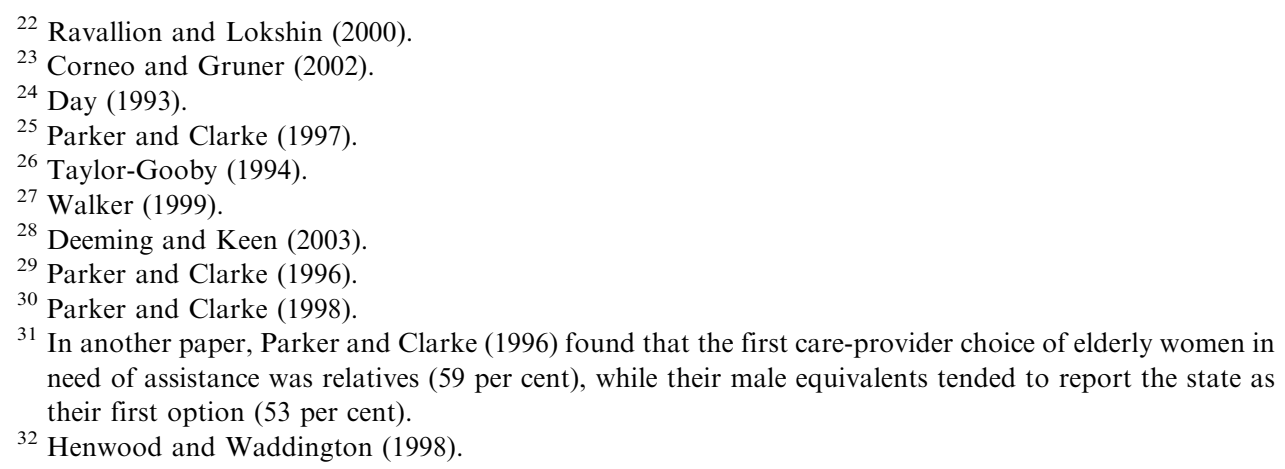


In some countries there is open debate on this question and many people question the extent to which individuals will be able to afford LTC costs. ${ }^{33}$ In Germany, the introduction of an LTC insurance system was included in the general social security system, partly due to public support for increasing social insurance coverage for LTC. $^{34}$ Other studies find evidence of strategic responses from a younger generation ${ }^{35}$ or, on the other hand, strategic responses of "median-middle-class" voters who wish to obtain more benefits by accessing the benefits of the less affluent at the expense of those more affluent than themselves. Evidence consistent with these arguments is found in the Republic of Ireland ${ }^{36}$ where, although 60 per cent of the population thought that funding LTC for the elderly should be the state's responsibility, almost 36 per cent felt that it should be the combined responsibility of the state and the family. ${ }^{37}$

\section{Data and methods}

\section{The data}

The data examined in this paper were taken from a public survey commissioned by the Spanish Ministry of Health in 2002. This is an ongoing survey that has been providing data on people's attitudes to the Spanish health service for the last two decades. ${ }^{38}$ The sample was made up of 6,801 interviews using stratified sampling methods and is representative of the 17 Autonomous Regions. The main purpose of this survey was to obtain information on Spanish people's views about how their health-care system worked, on the impact of health-policy measures, on the knowledge and attitudes with which Spanish people confront health problems, on the effectiveness of information campaigns and on the development of issues examined in previous periods.

The questionnaire included a large number of questions aimed at gathering information on how the health system worked along with some important questions on individual attitudes towards LTC. Respondents were asked a series of questions about who should be responsible for paying for support for the elderly and about the different care provision options.

\section{Variables}

\section{Dependent variables}

The study drew upon two main dependent variables to, respectively, respond to RQ1 and RQ2. First, a measure of preferences for the coverage of LTC services was derived

\footnotetext{
${ }^{33}$ Evandrou and Falkingham (1998); Deeming and Keen (2002).

${ }^{34}$ Geraedts et al. (2000).

${ }^{35}$ Deeming and Keen (2003).

${ }^{36}$ Williams et al. (2006).

${ }^{37}$ Most people were not in favour of increasing income tax to finance LTC, preferring an increase in social insurance contributions, and only 17 per cent said they would be prepared to pay $8 €$ a week (Williams et al., 2006). A similar study in Spain found that at feasible rates, only 17 per cent of the Catalan population would be prepared to purchase insurance against LTC (Costa-Font and Rovira, 2008).

${ }^{38}$ Barometro Sanitario (2002).
} 
from respondents' answers to the question "Who should cover LTC services?" (Question \#19). Responses were clustered into three categories: (a) the family, (b) the state and (c) a mixed model involving the family and the state. Second, the questionnaire included a question on individual preferences for different LTC funding options. The question was as follows: "Which of the following (funding) programmes do you think government bodies should set up?" (Question \#24). Responses were clustered as (a) economic support through a monthly cash payment to pay for care; (b) reduction of working hours for company employees (which implies that companies bear part of the costs of providing care to the elderly through regulation); and (c) tax relief for people providing care to the elderly. A categorical variable was constructed taking into account these responses: 1 for state funding (social insurance), 2 for company support and 3 for fiscal relief.

\section{Explanatory variables}

The two variables measuring the influence of self-interest were examined in this study, namely absolute and relative income. Income is important in that it measures "economic attitudes"; self-interest is thought to influence attitudes towards public/ private involvement in LTC. This is consistent with classical studies suggesting that income negatively affects the demand for some publicly provided private goods,${ }^{39}$ such as LTC. We construct two different measures of income: (i) absolute income computed as the logarithm of the monthly net household income; and (ii) relative income computed as the ratio between the monthly net household and the median of the monthly net household of the region.

The remainder are controls that include civil servant status, age, gender, educational attainment and institutional and regional controls (all defined in Table 1). Civil servants are hypothesised to be better informed about the extent of public coverage. Indeed, Lavis et $a l .{ }^{40}$ found that civil servants used information they gather from public sector benefits. ${ }^{41}$ Gender is important because there are marked differences between men and women respondents in the demand for particular public goods, and similarly education has a substantial impact on the demand for particular public services. ${ }^{42}$

Other socio-demographic controls include those for ability and knowledge such as age, cohabitation and education. As for socio-demographic variables, dummy variables were created to account for age group (a18-30, a31-40, etc.), for gender (male), for the living situation of the respondent (couple), for the highest level of studies completed (illiterate, primary studies, university studies) and for the different regions to enable regional clustering of the econometric specifications (see Table 1). Finally, the model took into account a set of regional and institutional variables measuring the extent of social use of home-help services and their price in the autonomous region where the respondent lived. The definition of public price was

\footnotetext{
${ }^{39}$ Strauss and Hughes (1976).

${ }^{40}$ Lavis et al. (2003).

${ }^{41}$ This is especially the case in Spain, where civil servants are entitled to publicly financed private health insurance. Gender has been found to influence attitudes towards the public sector.

42 Strauss and Hughes (1976).
} 
Socio-demographic controls

Male
a18_30
a31_40
a41_50
a51_60
a61_70
a71_80
Couple
Illiterate
Pristudies
Unistudie

Logarithm of total equivalent monthly net household income

Ratio of total equivalent income and the median income of the region state

Self-interest

作, 3 if both

Dummy variable: 1 if family; 0 otherwise

0.271

0.277

0.445

Dummy variable: 1 if both; 0 otherwise

0.447

Categorical variable: 1 if social insurance; 2 if company support; 3 fiscal relief

Dummy variable: 1 if social insurance; 0 otherwise

Dummy variable: 1 if company support; 0 otherwise

0.598

0.490

Company support

Dummy variable: 1 if fiscal relief; 0 otherwise

0.084

0.278

Fiscal relief

Dummy variable: 1 if male; 0 otherwise

Dummy variable: 1 if subject aged $18-30 ; 0$ otherwise

Dummy variable: 1 if subject aged $31-40 ; 0$ otherwise

Dummy variable: 1 if subject aged $41-50 ; 0$ otherwise

Dummy variable: 1 if subject aged 51-60; 0 otherwise

Dummy variable: 1 if subject aged $61-70 ; 0$ otherwise

Dummy variable: 1 if subject aged $71-80 ; 0$ otherwise

Dummy variable: 1 if subject live in a couple; 0 otherwise

Dummy variable: 1 if illiterate; 0 otherwise

0.257

0.437

0.176

0.381

0.169

0.375

$0.132 \quad 0.339$

a61_70

Dummy variable: 1 if primary studies; 0 otherwise

Unistudies

Dummy variable: 1 if university studies; 0 otherwise 
Table 1 Continued

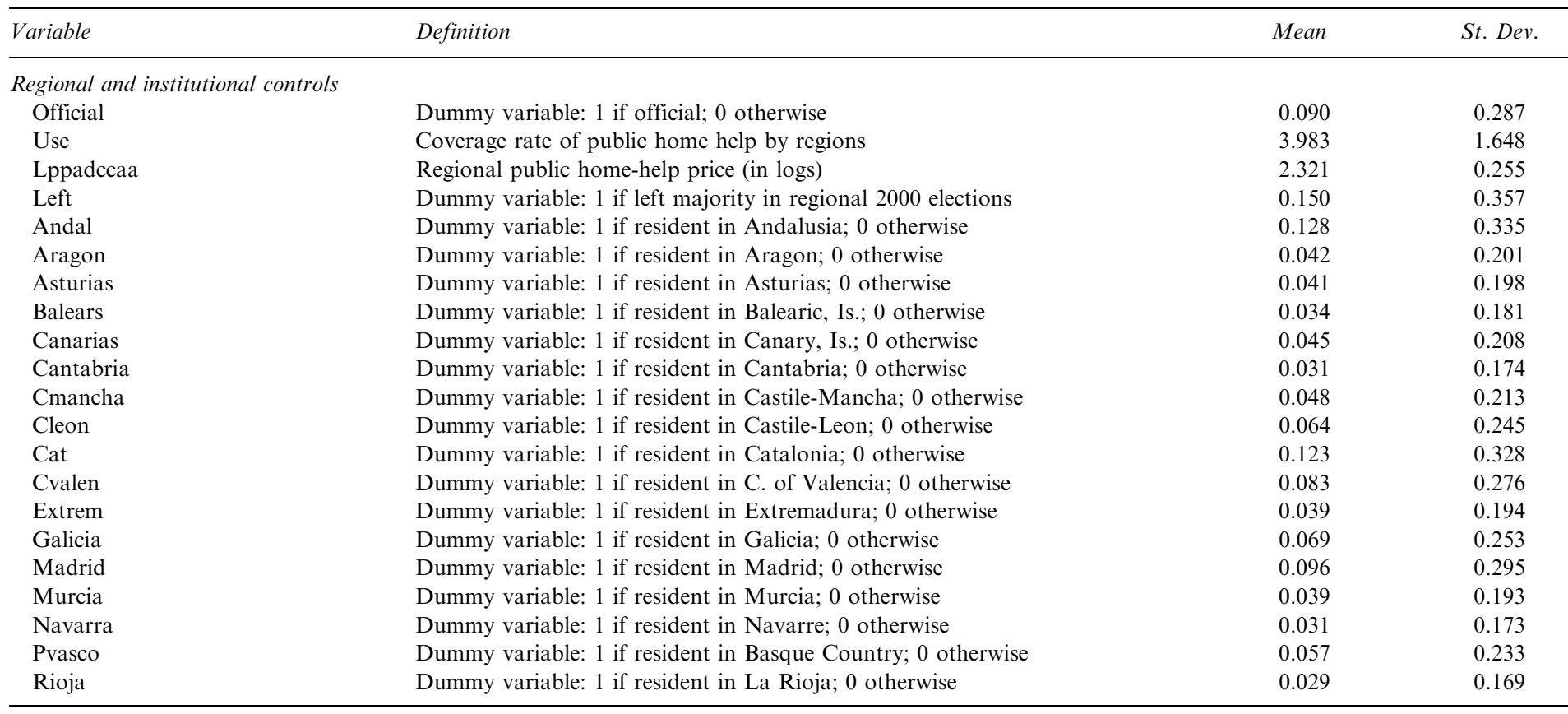


the price that an average citizen would have to (co-)pay in each autonomous region for each type of care. However, prices were likely to vary within regions and between different service providers. Finally, we include a variable to measure support for leftwing politics in each province in the relevant election for the year of the interview.

\section{Empirical model and specification}

Individuals are thought of as forming expectations of the future utility of different $j$ financing or insurance programmes based on what they expect to receive $\left(z_{i+1}\right)$ and pay $\left(w_{i+1}\right)$ at some future time $t+1$ as follows:

$$
\begin{aligned}
& E U_{1}\left(w_{t+1}, z_{t+1}\right) \\
& E U_{2}\left(w_{t+1}, z_{t+1}\right) \\
& \cdots \\
& E U_{j}\left(w_{t+1}, z_{t+1}\right)
\end{aligned}
$$

We do not observe the result of their utility trade-offs, but instead a latent variable that takes the value of one if a certain option $j$ was perceived as exerting a higher utility compared to another option. Therefore, we observe support for an alternative $j$ (e.g., state responsibility and/or social insurance) if its expected utility for respondents exceeds that of any other alternative $i$ as follows:

$$
E U_{j}\left(w_{t+1}, z_{t+1}\right) \leqslant E U_{i}\left(w_{t+1}, z_{t+1}\right)
$$

Therefore, the empirical specifications of the observed choices of support follow the lines of a multinomial logit model, that is, a regression model that generalises logistic regression by allowing more than two discrete outcomes. The multinomial logit specification assumes that the explanatory variable is case-specific, that is, that each independent variable has a single value for each case. The probability of each of the $i$ th alternatives $\left(y_{i}\right)$ takes the values specified in each equation ranging from 1 to $3 . x_{k}$ is a vector of explanatory variables measuring determinants of net utility calculation and $\beta_{j}$ is a vector of parameters. Thus, the probability of any individual supporting an alternative $j$ is

$$
\operatorname{Pr}\left(y_{i}=j\right)=\frac{\exp \left(\beta_{j} x_{k}\right)}{\sum_{j=0}^{2} \exp \left(\beta_{j} x_{k}\right)} \text { for } j=1,2,3
$$

Colinearity found to be below certain levels, tested using the well-known variance inflation factors, and independence from irrelevant alternatives were tested and found to be within acceptable levels. ${ }^{43}$ The study tested several specifications of the former

\footnotetext{
${ }^{43}$ After checking the odds ratio it was concluded that this was not a serious problem and that all alternatives were mutually exclusive and potentially substitutive.
} 
model in order to examine the particular effect of several explanations for individual attitudes to certain funding or provision options, and to shed light on the underlying determinants of support for each option in the contributions of each exogenous variable. $^{44}$

We find that 43 per cent of the respondents agree that both the state and the family have a role in covering LTC services and about 27-28 per cent agree, respectively, that the state or the family should be made responsible to cater for the old age dependent (Table 1, see Table A1 for the break up of responses by region state). As for the question regarding funding, we find that 84 per cent support social insurance as a funding system. Other financial instruments investigated are two financial instruments based on people's ability to pay, such as company support for families with frail elderly, or a fiscal relief that received the support of 12 and 4 per cent, respectively (see Table A2 for break up by region state). Interestingly, significant differences were found between the region states, which are in line with the decentralised nature of this government responsibility. ${ }^{45}$

We have then investigated in Figure 1 the association between support for different ways of allocating the responsibility for LTC/funding systems and regional income. Our findings point towards a mild association between state responsibility and per capita income, indicating that the affluent region states exhibit greater support for the option of public involvement. Similarly, we find aggregate association between individual support for various financing options and GDP per capita. The results showed only a mild positive association between income per capita and preferences for company support for caregivers. Furthermore, when we split the sample by income group, we find that as many as 36 per cent of relatively low-income respondents supported the idea of the family being responsible for LTC while only 32 per cent supported the view that the state should take on this responsibility. An exploration of socio-demographic patterns using the approach used by Parker and Clarke ${ }^{46}$ revealed that in the Spanish case 22 per cent of the "younger" age groups supported family responsibility for LTC, but that this increased to 25 per cent for middle-aged people and to 44 per cent for the elderly.

\section{Results}

Table 2 reports three different multinomial logistic regression specifications displaying the marginal effects, clustered standard error at the region state level and the presence of interaction effects. Results indicate that even though using a "naïve model" (that does not include relative income) fails to suggest income anchoring, the inclusion of

\footnotetext{
${ }^{44}$ Corneo and Gruner (2002).

${ }^{45}$ For instance, Valencia exhibited the highest level of support for family care (55.43 per cent) and one of the lowest levels for state care (12.5 per cent). La Rioja had the lowest support for state care (7.69 per cent). On the other hand, in the autonomous region of Madrid the first option was state care (53.85 per cent) and the second option was family care (16.83 per cent). 66.28 per cent of the respondents in Murcia thought that the mixed model, whereby both family and state contribute to the care of the elderly, was the best way to cover LTC. This was the highest value in the sample.

${ }^{46}$ Parker and Clarke (1996).
} 
Support for the placement of responsibility LTC ${ }^{a}$

Family responsibility

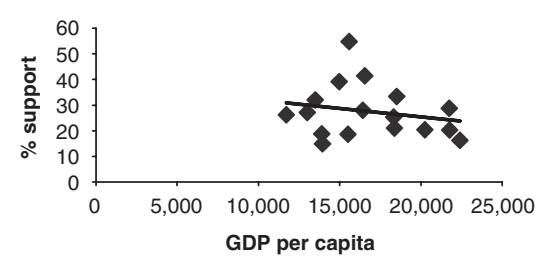

Support for LTC financing options ${ }^{b}$

Preference for Social Insurance

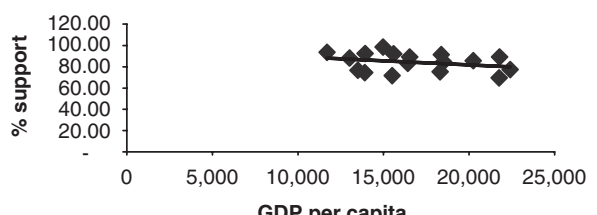

State responsibility

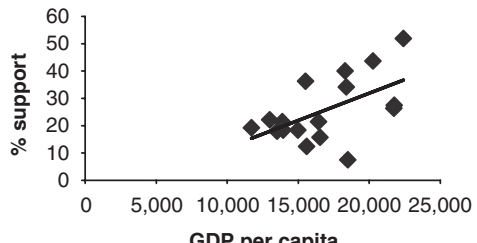

Preference for Company Support

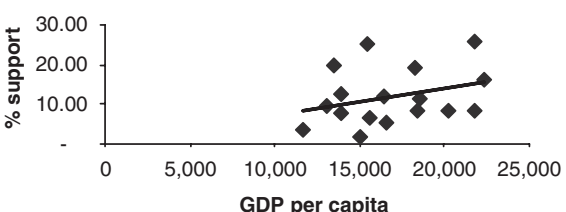

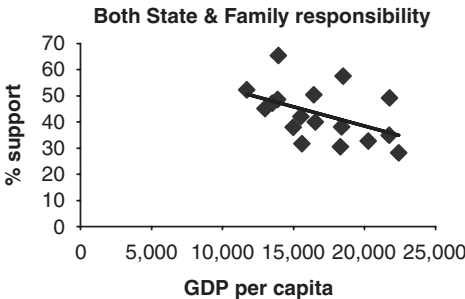

Preference for tax Relief

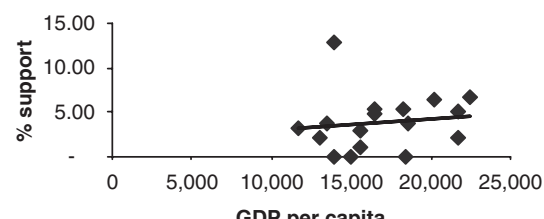

Figure 1. Regional income and attitudes to LTC responsibility, provision and financing. Source: own, data from the official Spanish Centre for Sociological Research (2002). The support values that made up 100 per cent were "don't knows" or "no answers". (a) "The increase in life expectancy has led to a need for more health and social care for dependent people. Who do you think should cover this need?" (Question \#21). (b) "Which of the following funding programmes do you think government bodies should set up?" (Question \#24). 
Table 2 Preference for LTC coverage (multinomial logistic regression for LTC coverage ( $=1$ if family, $=2$ if state, $=3$ if both)

\begin{tabular}{|c|c|c|c|c|c|c|c|c|c|}
\hline \multirow[t]{2}{*}{ Variables } & \multicolumn{3}{|c|}{ Family } & \multicolumn{3}{|c|}{ State } & \multicolumn{3}{|c|}{ Both } \\
\hline & $\begin{array}{c}d y / d x \\
\text { (s.e) }\end{array}$ & $\begin{array}{c}d y / d x \\
\text { (s.e) }\end{array}$ & $\begin{array}{c}d y / d x \\
\text { (s.e) }\end{array}$ & $\begin{array}{c}d y / d x \\
\text { (s.e) }\end{array}$ & $\begin{array}{c}d y / d x \\
\text { (s.e) }\end{array}$ & $\begin{array}{c}d y / d x \\
\text { (s.e) }\end{array}$ & $\begin{array}{c}d y / d x \\
\text { (s.e) }\end{array}$ & $\begin{array}{c}d y / d x \\
(s . e)\end{array}$ & $\begin{array}{c}d y / d x \\
(s . e)\end{array}$ \\
\hline \multicolumn{10}{|l|}{ Self-interest } \\
\hline$y_{i}(\log s)$ & $\begin{array}{c}0.034 \\
(0.027)\end{array}$ & $\begin{array}{c}-0.049 \\
(0.049)\end{array}$ & $\begin{array}{c}-0.498 \\
(0.311)\end{array}$ & $\begin{array}{c}-0.032 \\
(0.027)\end{array}$ & $\begin{array}{l}0.116^{* *} \\
(0.052)\end{array}$ & $\begin{array}{c}0.701 \\
(0.518)\end{array}$ & $\begin{array}{c}-0.003 \\
(0.030)\end{array}$ & $\begin{array}{c}-0.067 \\
(0.054)\end{array}$ & $\begin{array}{c}-0.203 \\
(0.415)\end{array}$ \\
\hline$y_{i} / \bar{y}$ & - & $\begin{array}{l}0.094 * * \\
(0.046)\end{array}$ & $\begin{array}{c}0.908^{*} \\
(0.541)\end{array}$ & - & $\begin{array}{c}-0.160^{* *} \\
(0.047)\end{array}$ & $\begin{array}{c}-1.333 \\
(0.925)\end{array}$ & - & $\begin{array}{c}0.066 \\
(0.049)\end{array}$ & $\begin{array}{c}0.425 \\
(0.721)\end{array}$ \\
\hline \multicolumn{10}{|l|}{ Controls } \\
\hline Official & $\begin{array}{c}-0.117 * * \\
(0.040)\end{array}$ & $\begin{array}{c}-0.118^{* *} \\
(0.038)\end{array}$ & $\begin{array}{c}-0.125^{* *} \\
(0.038)\end{array}$ & $\begin{array}{r}-0.013 \\
(0.045)\end{array}$ & $\begin{array}{c}-0.010 \\
(0.042)\end{array}$ & $\begin{array}{c}-0.005 \\
(0.043)\end{array}$ & $\begin{array}{l}0.129 * * \\
(0.050)\end{array}$ & $\begin{array}{l}0.129^{* *} \\
(0.047)\end{array}$ & $\begin{array}{l}0.130 * * \\
(0.047)\end{array}$ \\
\hline Left & $\begin{array}{c}-0.044 \\
(0.031)\end{array}$ & $\begin{array}{c}-0.047 \\
(0.030)\end{array}$ & $\begin{array}{r}-0.048 \\
(0.031)\end{array}$ & $\begin{array}{c}0.114 \\
(0.034)\end{array}$ & $\begin{array}{l}0.121^{* *} \\
(0.034)\end{array}$ & $\begin{array}{l}0.123^{* *} \\
(0.034)\end{array}$ & $\begin{array}{c}-0.070 \\
(0.034)\end{array}$ & $\begin{array}{c}-0.074 * * \\
(0.034)\end{array}$ & $\begin{array}{c}-0.076 * * \\
(0.034)\end{array}$ \\
\hline Lppadccaa & $\begin{array}{c}-0.076 \\
(0.049)\end{array}$ & $\begin{array}{c}-0.070 \\
(0.049)\end{array}$ & $\begin{array}{c}-0.067 \\
(0.049)\end{array}$ & $\begin{array}{c}0.175 \\
(0.047)\end{array}$ & $\begin{array}{l}0.157^{* *} \\
(0.047)\end{array}$ & $\begin{array}{l}0.152^{* *} \\
(0.047)\end{array}$ & $\begin{array}{c}-0.100^{* *} \\
(0.053)\end{array}$ & $\begin{array}{c}-0.088 \\
(0.053)\end{array}$ & $\begin{array}{c}-0.085 \\
(0.054)\end{array}$ \\
\hline Use & $\begin{array}{r}-0.029^{*} \\
(0.008)\end{array}$ & $\begin{array}{c}-0.028^{* *} \\
(0.008)\end{array}$ & $\begin{array}{c}-0.029^{* *} \\
(0.008)\end{array}$ & $\begin{array}{c}0.041 \\
(0.007)\end{array}$ & $\begin{array}{l}0.040^{* *} \\
(0.007)\end{array}$ & $\begin{array}{l}0.042^{* *} \\
(0.007)\end{array}$ & $\begin{array}{c}-0.012 \\
(0.008)\end{array}$ & $\begin{array}{c}-0.012 \\
(0.008)\end{array}$ & $\begin{array}{c}-0.012 \\
(0.008)\end{array}$ \\
\hline Male & $\begin{array}{c}-0.019 \\
(0.024)\end{array}$ & $\begin{array}{c}-0.021 \\
(0.024)\end{array}$ & $\begin{array}{c}-0.211 \\
(0.526)\end{array}$ & $\begin{array}{c}0.040 \\
(0.024)\end{array}$ & $\begin{array}{c}0.044 \\
(0.024)\end{array}$ & $\begin{array}{c}0.975^{* *} \\
(0.069)\end{array}$ & $\begin{array}{c}-0.021 \\
(0.026)\end{array}$ & $\begin{array}{c}-0.023 \\
(0.026)\end{array}$ & $\begin{array}{c}-0.764 \\
(0.514)\end{array}$ \\
\hline a18_30 & $\begin{array}{c}-0.160^{*} \\
(0.054)\end{array}$ & $\begin{array}{c}-0.161 * * \\
(0.054)\end{array}$ & $\begin{array}{c}-0.991 * * \\
(0.034)\end{array}$ & $\begin{array}{c}0.249 \\
(0.104)\end{array}$ & $\begin{array}{l}0.245^{* *} \\
(0.104)\end{array}$ & $\begin{array}{l}1.000^{* *} \\
(0.001)\end{array}$ & $\begin{array}{c}-0.089 \\
(0.088)\end{array}$ & $\begin{array}{c}-0.085 \\
(0.088)\end{array}$ & $\begin{array}{c}-0.009 \\
(0.034)\end{array}$ \\
\hline a31_40 & $\begin{array}{c}-0.160^{*} \\
(0.054)\end{array}$ & $\begin{array}{c}-0.188^{* *} \\
(0.049)\end{array}$ & $\begin{array}{c}-0.927^{* *} \\
(0.211)\end{array}$ & $\begin{array}{c}0.237 \\
(0.107)\end{array}$ & $\begin{array}{l}0.238^{* *} \\
(0.107)\end{array}$ & $\begin{array}{l}0.998^{* *} \\
(0.010)\end{array}$ & $\begin{array}{r}-0.050 \\
(0.093)\end{array}$ & $\begin{array}{c}-0.049 \\
(0.093)\end{array}$ & $\begin{array}{c}-0.071 \\
(0.208)\end{array}$ \\
\hline a41_50 & $\begin{array}{c}-0.213^{*} \\
(0.045)\end{array}$ & $\begin{array}{c}-0.214^{* *} \\
(0.045)\end{array}$ & $\begin{array}{c}-0.626 \\
(0.690)\end{array}$ & $\begin{array}{c}0.237^{*} \\
(0.108)\end{array}$ & $\begin{array}{l}0.236^{* *} \\
(0.108)\end{array}$ & $\begin{array}{c}0.994 * * \\
(0.031)\end{array}$ & $\begin{array}{c}-0.024 \\
(0.095)\end{array}$ & $\begin{array}{c}-0.022 \\
(0.096)\end{array}$ & $\begin{array}{c}-0.367 \\
(0.687)\end{array}$ \\
\hline a51_60 & $\begin{array}{c}-0.171^{*} \\
(0.049)\end{array}$ & $\begin{array}{c}-0.169 * * \\
(0.049)\end{array}$ & $\begin{array}{c}-0.961 * * \\
(0.084)\end{array}$ & $\begin{array}{c}0.208 \\
(0.111)\end{array}$ & $\begin{array}{c}0.201 \\
(0.110)\end{array}$ & $\begin{array}{l}0.997^{* *} \\
(0.013)\end{array}$ & $\begin{array}{r}-0.037 \\
(0.096)\end{array}$ & $\begin{array}{c}-0.032 \\
(0.096)\end{array}$ & $\begin{array}{c}-0.036 \\
(0.079)\end{array}$ \\
\hline a61_70 & $\begin{array}{c}-0.149^{*} \\
(0.051)\end{array}$ & $\begin{array}{c}-0.146^{* *} \\
(0.052)\end{array}$ & $\begin{array}{r}-0.608 \\
(0.568)\end{array}$ & $\begin{array}{l}0.187^{* *} \\
(0.108)\end{array}$ & $\begin{array}{c}0.181 \\
(0.107)\end{array}$ & $\begin{array}{l}0.989^{* *} \\
(0.043)\end{array}$ & $\begin{array}{r}-0.038 \\
(0.092)\end{array}$ & $\begin{array}{r}-0.034 \\
(0.093)\end{array}$ & $\begin{array}{r}-0.382 \\
(0.565)\end{array}$ \\
\hline a71_80 & $\begin{array}{c}-0.028 \\
(0.068)\end{array}$ & $\begin{array}{c}-0.025 \\
(0.069)\end{array}$ & $\begin{array}{c}-0.600 \\
(0.429)\end{array}$ & $\begin{array}{c}0.105 \\
(0.108)\end{array}$ & $\begin{array}{c}0.099 \\
(0.107)\end{array}$ & $\begin{array}{c}0.974 * * \\
(0.076)\end{array}$ & $\begin{array}{c}-0.077 \\
(0.088)\end{array}$ & $\begin{array}{c}-0.074 \\
(0.088)\end{array}$ & $\begin{array}{c}-0.374 \\
(0.425)\end{array}$ \\
\hline Couple & $\begin{array}{c}-0.001 \\
(0.028)\end{array}$ & $\begin{array}{c}0.001 \\
(0.028)\end{array}$ & $\begin{array}{c}0.005 \\
(0.029)\end{array}$ & $\begin{array}{c}0.029 \\
(0.028)\end{array}$ & $\begin{array}{c}0.025 \\
(0.028)\end{array}$ & $\begin{array}{c}0.021 \\
(0.028)\end{array}$ & $\begin{array}{c}-0.028 \\
(0.031)\end{array}$ & $\begin{array}{c}-0.027 \\
(0.031)\end{array}$ & $\begin{array}{c}-0.025 \\
(0.032)\end{array}$ \\
\hline Illiterate & $\begin{array}{c}0.220 \\
(0.091)\end{array}$ & $\begin{array}{c}0.208^{* *} \\
(0.091)\end{array}$ & $\begin{array}{l}0.226^{* *} \\
(0.092)\end{array}$ & $\begin{array}{c}-0.009 \\
(0.082)\end{array}$ & $\begin{array}{c}0.009 \\
(0.085)\end{array}$ & $\begin{array}{c}-0.009 \\
(0.082)\end{array}$ & $\begin{array}{c}-0.211 \\
(0.071)\end{array}$ & $\begin{array}{c}-0.217^{* *} \\
(0.070)\end{array}$ & $\begin{array}{c}-0.216^{* *} \\
(0.072)\end{array}$ \\
\hline Pristudies & $\begin{array}{c}0.060 \\
(0.028)\end{array}$ & $\begin{array}{c}0.062 * * \\
(0.028)\end{array}$ & $\begin{array}{l}0.067 * * \\
(0.029)\end{array}$ & $\begin{array}{c}0.003 \\
(0.029)\end{array}$ & $\begin{array}{c}0.002 \\
(0.029)\end{array}$ & $\begin{array}{c}0.003 \\
(0.029)\end{array}$ & $\begin{array}{c}-0.063 \\
(0.031)\end{array}$ & $\begin{array}{c}-0.063^{* *} \\
(0.031)\end{array}$ & $\begin{array}{c}-0.069 * * \\
(0.032)\end{array}$ \\
\hline Unistudies & $\begin{array}{c}-0.063 \\
(0.041)\end{array}$ & $\begin{array}{c}-0.072 \\
(0.041)\end{array}$ & $\begin{array}{c}-0.066 \\
(0.042)\end{array}$ & $\begin{array}{c}0.046 \\
(0.042)\end{array}$ & $\begin{array}{c}0.062 \\
(0.044)\end{array}$ & $\begin{array}{c}0.055 \\
(0.044)\end{array}$ & $\begin{array}{c}0.017 \\
(0.045)\end{array}$ & $\begin{array}{c}0.010 \\
(0.045)\end{array}$ & $\begin{array}{c}0.012 \\
(0.046)\end{array}$ \\
\hline Interactions & No & No & Yes & No & No & Yes & No & No & Yes \\
\hline LR test & 145.7 & 157.42 & 180.98 & & & & & & \\
\hline Pseudo- $R^{2}$ & 0.0433 & 0.0468 & 0.0538 & & & & & & \\
\hline Log likelih. & $-1,609.7$ & $-1,603.85$ & $-1,592.1$ & & & & & & \\
\hline
\end{tabular}

Note: $* *$ Significant at least at 5 per cent. Coefficients are marginal effect and standard errors are clustered by region.

relative income does exert a robust and significant influence increasing the probability of respondents supporting the family role in LTC. Indeed, higher individual income relative to that of the median income of the respondent's region of residence increases the probability of support to the family for LTC, and reduces that of the state. 
However, following previous evidence we find that absolute income does exert a combined influence in supporting state intervention, although the effect fades away when interactions with an individual's age are included as discussed later on. Therefore, an individual's relative income does stand behind attitudes towards the role of the state/family in LTC coverage. This leads us to tentatively conclude that there is some evidence of a dissociation of absolute and relative income, although affected by individual heterogeneity. The latter result can be explained in the light of the institutional organisation of public support for LTC in Spain. Furthermore, it suggests that a higher relative income will increase the preference for family as the key institution in the coverage of LTC needs.

In examining controls in Table 2, we find that individuals' civil servant status displays a robust coefficient, suggesting that civil servants are less likely to support the family but more likely to support both family and state involvement (by an equivalent magnitude but with an opposite sign). As expected, individuals who live in a constituency where the political left received relatively higher support are more likely to support state responsibility for LTC. Those living in region states with relatively higher price of LTC services and higher intensity of use are more likely to go public. Gender increases the likelihood for state support consistent with our expectations; relatively younger individuals are more likely to support state involvement, although age effects are non-linear. Finally, literacy reduces the probability of family involvement in LTC coverage.

Table 3 displays the results of the multinomial logistic regression for different funding systems for LTC, and particularly for social insurance. As before, our findings suggest further evidence that more affluent individuals are less likely to support social insurance funding (where funding is fully based on ability to pay), while they appear to be more likely to support other financing options (e.g., company support) for LTC financing. When interactions are included, these effects are found to concentrate in the generation that is a decade to retirement - the 51-60 age group - who perhaps has already identified alternative sources of funding. No income effects are found for the fiscal relief option. Civil servant status did not explain the probability of supporting any specific LTC financing alternative. As expected, respondents who reside in areas with high left-wing support are more likely to support social insurance, and less likely to support private alternatives by a similar magnitude. Interestingly, respondents who live in areas with higher prices for LTC are more likely to support company support for LTC financing. Men are less likely to support social insurance and more likely to go private than women. With the exception of the age group that is up to retiring - the 61-70 age group - all other age groups exhibit similar coefficients in their support for social insurance. Cohabitation and literacy do not appear to exert a specific effect on attitudes.

To complement previous findings, Table 4 reports interactions effects with age groups and gender. Here, we find that income effects concentrate in certain age groups close to retirement. Indeed, the relatively more affluent individuals from ages 50 to 60 are more likely to support the family as an institution that is responsible for LTC coverage. Similarly, more affluent individuals aged 51-60 appear to be 30 per cent less likely to support social insurance and 32 per cent more likely to support company support as a source of funding LTC (see Table 4). Overall, these results suggest that 
Table 3 Preference for LTC funding (multinomial logistic regression LTC funding (=1 if social insurance, $=2$ if company support, $=3$ if fiscal relief)

\begin{tabular}{|c|c|c|c|c|c|c|c|c|c|}
\hline \multirow[t]{2}{*}{ Variables } & \multicolumn{3}{|c|}{ Social insurance } & \multicolumn{3}{|c|}{ Company support } & \multicolumn{3}{|c|}{ Fiscal relief } \\
\hline & $\begin{array}{c}d y / d x \\
\text { (s.e) }\end{array}$ & $\begin{array}{c}d y / d x \\
(s . e)\end{array}$ & $\begin{array}{c}d y / d x \\
\text { (s.e) }\end{array}$ & $\begin{array}{c}d y / d x \\
\text { (s.e) }\end{array}$ & $\begin{array}{c}d y / d x \\
\text { (s.e) }\end{array}$ & $\begin{array}{c}d y / d x \\
(s . e)\end{array}$ & $\begin{array}{c}d y / d x \\
\text { (s.e) }\end{array}$ & $\begin{array}{c}\mathrm{dy} / \mathrm{dx} \\
\text { (s.e) }\end{array}$ & $\begin{array}{c}\mathrm{dy} / \mathrm{dx} \\
\text { (s.e) }\end{array}$ \\
\hline \multicolumn{10}{|l|}{ Self-interest } \\
\hline$y_{i}(\operatorname{logs})$ & $\begin{array}{c}-0.075^{* *} \\
(0.021)\end{array}$ & $\begin{array}{c}-0.107 * * \\
(0.043)\end{array}$ & $\begin{array}{c}-0.093 \\
(0.093)\end{array}$ & $\begin{array}{l}0.068^{* *} \\
(0.019)\end{array}$ & $\begin{array}{l}0.076^{* *} \\
(0.038)\end{array}$ & $\begin{array}{c}0.096 \\
(0.0849\end{array}$ & $\begin{array}{c}0.008 \\
(0.011)\end{array}$ & $\begin{array}{c}0.031 \\
(0.022)\end{array}$ & $\begin{array}{c}-0.003 \\
(0.042)\end{array}$ \\
\hline$y_{i} / \bar{y}$ & - & $\begin{array}{c}0.031 \\
(0.035)\end{array}$ & $\begin{array}{c}-0.086 \\
(0.203)\end{array}$ & - & $\begin{array}{c}-0.007 \\
(0.030)\end{array}$ & $\begin{array}{c}0.038 \\
(0.182)\end{array}$ & - & $\begin{array}{c}-0.024 \\
(0.019)\end{array}$ & $\begin{array}{c}0.048 \\
(0.082)\end{array}$ \\
\hline \multicolumn{10}{|l|}{ Controls } \\
\hline Official & $\begin{array}{c}-0.066 \\
(0.040)\end{array}$ & $\begin{array}{c}-0.069 \\
(0.040)\end{array}$ & $\begin{array}{c}-0.052 \\
(0.037)\end{array}$ & $\begin{array}{c}0.033 \\
(0.033)\end{array}$ & $\begin{array}{c}0.033 \\
(0.033)\end{array}$ & $\begin{array}{c}0.027 \\
(0.032)\end{array}$ & $\begin{array}{c}0.033 \\
(0.025)\end{array}$ & $\begin{array}{c}0.035 \\
(0.026)\end{array}$ & $\begin{array}{c}0.025 \\
(0.021)\end{array}$ \\
\hline Left & $\begin{array}{l}0.063 * * \\
(0.022)\end{array}$ & $\begin{array}{l}0.063 * * \\
(0.022)\end{array}$ & $\begin{array}{l}0.060 * * \\
(0.020)\end{array}$ & $\begin{array}{c}-0.066^{* *} \\
(0.017)\end{array}$ & $\begin{array}{c}-0.066^{* *} \\
(0.017)\end{array}$ & $\begin{array}{c}-0.065^{* *} \\
(0.016)\end{array}$ & $\begin{array}{c}0.003 \\
(0.014)\end{array}$ & $\begin{array}{c}0.003 \\
(0.014)\end{array}$ & $\begin{array}{c}0.004 \\
(0.012)\end{array}$ \\
\hline Lppadccaa & $\begin{array}{c}-0.052 \\
(0.036)\end{array}$ & $\begin{array}{c}-0.050 \\
(0.036)\end{array}$ & $\begin{array}{c}-0.046 \\
(0.033)\end{array}$ & $\begin{array}{l}0.071^{* *} \\
(0.030)\end{array}$ & $\begin{array}{l}0.070^{* *} \\
(0.030)\end{array}$ & $\begin{array}{l}0.065^{* *} \\
(0.029)\end{array}$ & $\begin{array}{c}-0.020 \\
(0.020)\end{array}$ & $\begin{array}{c}-0.020 \\
(0.020)\end{array}$ & $\begin{array}{c}-0.019 \\
(0.017)\end{array}$ \\
\hline Use & $\begin{array}{c}-0.002 \\
(0.006)\end{array}$ & $\begin{array}{c}-0.001 \\
(0.006)\end{array}$ & $\begin{array}{c}-0.002 \\
(0.005)\end{array}$ & $\begin{array}{c}0.003 \\
(0.005)\end{array}$ & $\begin{array}{c}0.003 \\
(0.005)\end{array}$ & $\begin{array}{c}0.003 \\
(0.005)\end{array}$ & $\begin{array}{c}-0.001 \\
(0.003)\end{array}$ & $\begin{array}{c}-0.002 \\
(0.003)\end{array}$ & $\begin{array}{c}-0.001 \\
(0.003)\end{array}$ \\
\hline Male & $\begin{array}{l}0.000 \\
(0.019)\end{array}$ & $\begin{array}{c}0.001 \\
(0.019)\end{array}$ & $\begin{array}{c}-0.992 * * \\
(0.040)\end{array}$ & $\begin{array}{c}-0.027^{*} \\
(0.016)\end{array}$ & $\begin{array}{c}-0.027^{*} \\
(0.016)\end{array}$ & $\begin{array}{l}0.978^{* *} \\
(0.153)\end{array}$ & $\begin{array}{l}0.027 * * \\
(0.011)\end{array}$ & $\begin{array}{l}0.027^{* *} \\
(0.010)\end{array}$ & $\begin{array}{c}0.014 \\
(0.135)\end{array}$ \\
\hline a31_40 & $\begin{array}{l}0.058^{* *} \\
(0.022)\end{array}$ & $\begin{array}{l}0.058^{* *} \\
(0.022)\end{array}$ & $\begin{array}{c}0.006 \\
(0.076)\end{array}$ & $\begin{array}{c}-0.038^{* * *} \\
(0.019)\end{array}$ & $\begin{array}{c}-0.038^{* *} \\
(0.019)\end{array}$ & $\begin{array}{l}0.994^{* *} \\
(0.076)\end{array}$ & $\begin{array}{c}-0.020^{* *} \\
(0.011)\end{array}$ & $\begin{array}{c}-0.020^{*} \\
(0.011)\end{array}$ & $\begin{array}{c}-1.000^{* *} \\
(0.003)\end{array}$ \\
\hline a41_50 & $\begin{array}{l}0.057^{* *} \\
(0.023)\end{array}$ & $\begin{array}{l}0.056^{* *} \\
(0.023)\end{array}$ & $\begin{array}{l}0.968^{* *} \\
(0.189)\end{array}$ & $\begin{array}{c}-0.026 \\
(0.021)\end{array}$ & $\begin{array}{c}-0.026 \\
(0.021)\end{array}$ & $\begin{array}{c}-0.044 \\
(0.285)\end{array}$ & $\begin{array}{c}-0.031^{* *} \\
(0.010)\end{array}$ & $\begin{array}{c}-0.030^{* *} \\
(0.010)\end{array}$ & $\begin{array}{c}-0.924 * * \\
(0.463)\end{array}$ \\
\hline a51_60 & $\begin{array}{c}0.048^{*} \\
(0.025)\end{array}$ & $\begin{array}{l}0.049 * * \\
(0.025)\end{array}$ & $\begin{array}{c}0.180 \\
(2.678)\end{array}$ & $\begin{array}{c}-0.050 * * \\
(0.020)\end{array}$ & $\begin{array}{c}-0.050^{* *} \\
(0.020)\end{array}$ & $\begin{array}{c}-0.981^{* *} \\
(0.069)\end{array}$ & $\begin{array}{c}0.002 \\
(0.015)\end{array}$ & $\begin{array}{c}0.001 \\
(0.015)\end{array}$ & $\begin{array}{c}0.801 \\
(2.675)\end{array}$ \\
\hline a61_70 & $\begin{array}{c}0.014 \\
(0.030)\end{array}$ & $\begin{array}{c}0.013 \\
(0.030)\end{array}$ & $\begin{array}{c}0.623 \\
(0.809)\end{array}$ & $\begin{array}{c}-0.012 \\
(0.026)\end{array}$ & $\begin{array}{c}-0.012 \\
(0.026)\end{array}$ & $\begin{array}{c}-0.035 \\
(0.288)\end{array}$ & $\begin{array}{r}-0.002 \\
(0.016)\end{array}$ & $\begin{array}{r}-0.001 \\
(0.016)\end{array}$ & $\begin{array}{r}-0.589 \\
(0.859)\end{array}$ \\
\hline a71_80 & $\begin{array}{l}0.058 * * \\
(0.029)\end{array}$ & $\begin{array}{l}0.057 * * \\
(0.029)\end{array}$ & $\begin{array}{l}0.986^{* *} \\
(0.066)\end{array}$ & $\begin{array}{c}-0.049 * * \\
(0.024)\end{array}$ & $\begin{array}{c}-0.049^{* *} \\
(0.024)\end{array}$ & $\begin{array}{c}-0.001 \\
(0.028)\end{array}$ & $\begin{array}{r}-0.009 \\
(0.016)\end{array}$ & $\begin{array}{r}-0.008 \\
(0.016)\end{array}$ & $\begin{array}{c}-0.984 * * \\
(0.071)\end{array}$ \\
\hline Couple & $\begin{array}{c}-0.013 \\
(0.022)\end{array}$ & $\begin{array}{c}-0.013 \\
(0.022)\end{array}$ & $\begin{array}{c}-0.009 \\
(0.021)\end{array}$ & $\begin{array}{c}0.021 \\
(0.019)\end{array}$ & $\begin{array}{c}0.020 \\
(0.019)\end{array}$ & $\begin{array}{c}0.016 \\
(0.019)\end{array}$ & $\begin{array}{r}-0.007 \\
(0.013)\end{array}$ & $\begin{array}{c}-0.007 \\
(0.012)\end{array}$ & $\begin{array}{c}-0.007 \\
(0.011)\end{array}$ \\
\hline Pristudies & $\begin{array}{c}-0.011 \\
(0.022)\end{array}$ & $\begin{array}{c}-0.011 \\
(0.022)\end{array}$ & $\begin{array}{c}-0.005 \\
(0.021)\end{array}$ & $\begin{array}{c}0.005 \\
(0.019)\end{array}$ & $\begin{array}{c}0.005 \\
(0.019)\end{array}$ & $\begin{array}{c}0.002 \\
(0.019)\end{array}$ & $\begin{array}{c}0.006 \\
(0.012)\end{array}$ & $\begin{array}{c}0.006 \\
(0.011)\end{array}$ & $\begin{array}{c}0.003 \\
(0.010)\end{array}$ \\
\hline Unistudies & $\begin{array}{c}-0.024 \\
(0.033)\end{array}$ & $\begin{array}{c}-0.026 \\
(0.034)\end{array}$ & $\begin{array}{r}-0.023 \\
(0.031)\end{array}$ & $\begin{array}{c}0.004 \\
(0.027)\end{array}$ & $\begin{array}{c}0.004 \\
(0.027)\end{array}$ & $\begin{array}{c}0.008 \\
(0.027)\end{array}$ & $\begin{array}{c}0.020 \\
(0.021)\end{array}$ & $\begin{array}{c}0.021 \\
(0.022)\end{array}$ & $\begin{array}{c}0.015 \\
(0.017)\end{array}$ \\
\hline Interactions & No & No & Yes & No & No & Yes & No & No & Yes \\
\hline LR test & 73.090 & 74.84 & 100.45 & & & & & & \\
\hline Pseudo- $R^{2}$ & 0.063 & 0.064 & 0.086 & & & & & & \\
\hline Log likelih. & -545.760 & -544.89 & -532.08 & & & & & & \\
\hline
\end{tabular}

Note: **Significant at least at 5 per cent. Coefficients are marginal effect and standard errors are clustered by region.

the coefficient for these groups is three times larger than that of the general population in explaining support for social insurance.

Finally, in the Results section we have not examined the magnitude of the coefficients, because Table 5 already reports the elasticity coefficients for both the role of state/family in covering LTC and the three funding systems examined. The interpretation of these elasticities is as follows. Doubling the respondents' relative income - increasing income by 100 per cent - results in a 36 per cent increase in the 
The Geneva Papers on Risk and Insurance - Issues and Practice 688

Table 4 Interactions effects (marginal effects $\mathrm{dy} / \mathrm{dx}$ )

\begin{tabular}{|c|c|c|c|c|c|c|}
\hline & \multicolumn{3}{|c|}{ LTC coverage } & \multicolumn{3}{|c|}{ LTC funding } \\
\hline & Family & State & Both & $\begin{array}{c}\text { Social } \\
\text { insurance }\end{array}$ & $\begin{array}{c}\text { Company } \\
\text { support }\end{array}$ & $\begin{array}{l}\text { Fiscal } \\
\text { relief }\end{array}$ \\
\hline \multicolumn{7}{|c|}{ Interactions with absolute income } \\
\hline$y_{i} \times$ Male & 0.041 & -0.167 & 0.126 & 0.116 & -0.102 & -0.014 \\
\hline$y_{i} \times \mathrm{a} 18-30$ & 0.565 & -0.518 & -0.047 & -0.004 & 0.001 & 0.004 \\
\hline$y_{i} \times$ a31_40 & 0.432 & -0.457 & 0.025 & -0.080 & -0.072 & 0.152 \\
\hline$y_{i} \times$ a41_50 & 0.265 & -0.451 & 0.186 & -0.186 & 0.098 & 0.088 \\
\hline$y_{i} \times$ a51_60 & 0.640 & -0.499 & -0.142 & $-0.304 * *$ & $0.324 * *$ & -0.020 \\
\hline$y_{i} \times$ a61_70 & 0.284 & -0.463 & 0.179 & -0.074 & 0.008 & 0.066 \\
\hline$y_{i} \times$ a71_80 & 0.329 & -0.476 & 0.147 & -0.203 & 0.021 & 0.181 \\
\hline \multicolumn{7}{|c|}{ Interactions with relative income } \\
\hline$y_{i} / \bar{y} \times$ Male & -0.021 & 0.088 & -0.067 & -0.093 & 0.086 & 0.007 \\
\hline$y_{i} / \bar{y} \times$ a $18-30$ & -0.875 & 1.152 & -0.277 & 0.116 & -0.060 & -0.056 \\
\hline$y_{i} / \bar{y} \times$ a31_40 & -0.813 & 1.101 & -0.287 & 0.212 & -0.064 & -0.147 \\
\hline$y_{i} / \bar{y} \times$ a41_50 & -0.723 & 1.157 & -0.435 & 0.191 & -0.102 & -0.090 \\
\hline$y_{i} / \bar{y} \times$ a51_60 & $0.995 * *$ & 1.109 & -0.114 & 0.373 & -0.357 & -0.016 \\
\hline$y_{i} / \bar{y} \times$ a61_70 & -0.679 & 1.013 & -0.335 & $0.128 * *$ & -0.043 & -0.085 \\
\hline$y_{i} / \bar{y} \times$ a71_80 & -0.491 & 0.791 & -0.299 & 0.371 & -0.145 & -0.225 \\
\hline
\end{tabular}

Note: **Significant at least at 5 per cent.

Table 5 Elasticity estimates $(\eta)$ and standard errors in brackets

\begin{tabular}{|c|c|c|c|c|c|c|}
\hline \multirow[b]{2}{*}{$y_{i}(\log s)$} & \multicolumn{2}{|c|}{ Family } & \multicolumn{2}{|c|}{ State } & \multicolumn{2}{|c|}{ Both } \\
\hline & $\begin{array}{c}0.120 \\
(0.096)\end{array}$ & $\begin{array}{r}-0.170 \\
(0.171)\end{array}$ & $\begin{array}{r}-0.113 \\
(0.094)\end{array}$ & $\begin{array}{l}0.407 * * \\
(0.182)\end{array}$ & $\begin{array}{r}-0.005 \\
(0.069)\end{array}$ & $\begin{array}{r}-0.156 \\
(0.126)\end{array}$ \\
\hline$y_{i} / \bar{y}$ & - & $\begin{array}{l}0.365^{* *} \\
(0.178)\end{array}$ & - & $\begin{array}{c}-0.628^{* *} \\
(0.188)\end{array}$ & - & $\begin{array}{c}0.173 \\
(0.127)\end{array}$ \\
\hline & \multicolumn{2}{|c|}{ Social insurance } & \multicolumn{2}{|c|}{ Company support } & \multicolumn{2}{|c|}{ Fiscal relief } \\
\hline$y_{i}(\operatorname{logs})$ & $\begin{array}{c}-0.086^{* *} \\
(0.024)\end{array}$ & $\begin{array}{c}-0.122 * * \\
(0.049)\end{array}$ & $\begin{array}{l}0.746^{* *} \\
(0.216)\end{array}$ & $\begin{array}{l}0.84 * * \\
(0.42)\end{array}$ & $\begin{array}{c}0.235 \\
(0.330)\end{array}$ & $\begin{array}{c}0.981 \\
(0.699)\end{array}$ \\
\hline$y_{i} / \bar{y}$ & - & $\begin{array}{c}0.035 \\
(0.039)\end{array}$ & - & $\begin{array}{r}-0.080 \\
(0.326)\end{array}$ & - & $\begin{array}{c}-0.748 \\
(0.608)\end{array}$ \\
\hline
\end{tabular}

support of the family and a reduced 62 per cent support for the state as being responsible for LTC coverage. Similarly doubling absolute income, after controlling for relative income effects, increases by 40 per cent support of the state, which indicates that while self-interest is likely to play a role through relative income, absolute income exerts the opposite effect. Estimated elasticities for attitudes towards a financial option suggest that doubling individual income reduces support for social insurance by 9-12 per cent, and increases the likelihood of the respondents backing company support as an instrument to finance LTC by $74-83$ per cent. 


\section{Discussion}

This paper has empirically explored the hypothesis of individual attitudes towards LTC funding in Spain as being anchored in the individuals' absolute and relative income (affluence). The data employed are from a time where no pre-existing entitlement to LTC funding was yet in place in Spain, so that attitudes express demands for some type of insurance design. Our contribution lies in examining how people form their insurance choices, and more particularly in what individuals take into account when judging several LTC coverage and financing alternatives.

Our findings suggest that attitudes towards the coverage and financing of LTC are anchored in the individual's income, but in a rather non-straightforward way. Relatively less (more) affluent individuals are found to be less (more) likely to support a more intensive role of the state as being responsible for LTC coverage after controlling for institutional and socio-demographic effects. However, in exploring attitudes towards the role of the state in LTC coverage, we find some evidence of a clear dissociation between absolute and relative income effects, where more affluent individuals in comparatively less affluent areas countrywide are less likely to support a wider role of the state in covering LTC. The latter is consistent with the idea that preferences towards the role of state intervention are regionally formed.

Nevertheless, attitudes towards social insurance and other financing instruments (e.g., company support) are instead explained by absolute income solely. Therefore, these results would suggest that preferences for redistribution in LTC are influenced by absolute income countrywide. Furthermore, when income-anchoring effects are examined at different age groups, we find significant differences between age groups. That is, we find that income anchoring tends to concentrate in age groups close to retirement - who arguably have already saved for old age through their own means.

Our explanation of these results is as follows. First, the dissociation between absolute and relative income effects in explaining general attitudes might indicate that individual reference groups for attitude formation are heterogeneous. Consistent with the happiness literature, ${ }^{47}$ people appear to compare themselves with others of the same reference group. Other weaker explanations more in line with some old findings ${ }^{48}$ would point towards a higher attachment to the status quo of the less affluent individuals. Finally, given the heterogeneity of Spain as a state, it seems plausible that people compare themselves with those of their same region state. Indeed, this has to do with the devolved nature of LTC in Spain, where public support is both means and needs tested, at least regionally. ${ }^{49}$ In contrast, attitudes towards social security as a countrywide financing scheme to finance LTC - which has large redistributive implications - appear to be driven by absolute income only. Support for social insurance declines with an individual's income and an expected support for other financing options, namely company support, is positively associated with an individual's income. Interestingly, these results are especially concentrated in those

\footnotetext{
47 Layard, 2005.

${ }^{48}$ Runciman (1972).

${ }^{49}$ Costa-Font and Font-Vilalta (2006).
} 
690

individuals a decade to retirement. Hence, rather than a desire to free ride (whereby the relatively poor wish to copy the attitudes of affluent people) by the relatively poor, we are inclined to think that our results reflect an unwillingness of the relatively more affluent individuals to support a financing system, where they would not expect to benefit from income transfers.

The policy implications of these results suggest that attitudes are a valuable information to guide public and private LTC insurance design. Relative affluence at the region state level is a key determinant of attitudes towards the role of the state and the family. A larger role of the state in LTC coverage would be opposed by relatively more affluent individuals at the regional level, though not by the affluent countrywide. Consistent with a public choice type of expectation, in designing LTC instruments, more affluent individuals are less likely to support a countrywide entitlement in the form of a social security system and more likely to support other alternative financial instruments. Interestingly, low support by the most affluent seems to have driven the 2007 LTC reform. Indeed, an expansion of the social security was not the option chosen by the government (even though it had a large support), and instead a taxfinanced programme was put in place, with the central state only financing one-third of the total LTC expenditure. The remaining two-thirds are expected to be financed by region states and individuals themselves through co-payments.

Some caveats and further explanations must be mentioned. Primarily, individuals might be argued to exhibit cognitive limitations in forming expectations about their future well-being. Furthermore, the results might be affected by the presence of some status quo bias, ${ }^{50}$ namely that more affluent individuals wish to protect their expected future income and savings, and are less likely to support options that weaken the role of the family (traditionally the main source of support for LTC). The existence of only cross-sectional data does not allow for controlling of unobservable effects, which require longitudinal databases. Future research might need to address these effects along with the responses to payment mechanisms and institutional constraints. ${ }^{51}$

\section{Acknowledgements}

We thank Christophe Courbage along with three anonymous referees for their comments. We are grateful to Joan Rovira, Jaume Puig, Josep Lluis Carrion and Fernando Sanchez Losada for commenting on a previous version of the paper. Needless to say, any mistakes are the sole responsibility of the authors themselves. We wish to acknowledge the financial support from the Xarxa de Recerca en Economia de les Polítiques Públiques, and Joan Costa-Font is grateful to the Institut Ramon Llull, Generalitat de Catalunya.

\section{References}

Ajzen, I. (1991) 'The theory of planned behavior', Organizational Behavior and Human Decision Processes 50: $179-211$

\footnotetext{
${ }^{50}$ Kahneman et al. (1991).

${ }^{51}$ Indeed, evidence from Britain (Parker and Clarke, 1996) showed that only 7 per cent of individuals changed their attitude when the question included information on a potential tax increase.
} 
Barometro Sanitario (2002) 'Ministerio de Sanidad y Consumo', http://www.msc.es/Diseno/sns/sns_ sistemas_informacion.htm $\backslash$.

Beshears, J.L., Choi, J.J., Laibson, D. and Madrian, C. (2008) How are preferences revealed?, NBER Working Paper 13976, Washington, DC.

Castles, F. (2005) 'Social expenditure in the 1990s: Data and determinants', Policy \& Politics 33: 411-430.

Clark, A.E., Frijters, P. and Shields, M.A. (2006) Income and happiness: Evidence, explanations and economic implications, Working Paper 2006-24, Jourdan Sciences Economiques, Paris.

Clark, A.E. and Oswald, A.J. (1996) 'Satisfaction and comparison income', Journal of Public Economics 61: 359-381.

Corneo, G. and Gruner, H.P. (2002) 'Individual's preferences for political redistribution', Journal of Public Economics 83: 83-107.

Costa-Font, J. and Font-Vilalta, M. (2006) 'The limits to the design of long term care insurance schemes: The Spanish experience in comparative research', International Social Security Review 59: 91-110.

Costa-Font, J. and Font-Vilalta, M. (2008) 'Risk perceptions, myopia and the willingness to pay for long term care insurance in Catalonia', Applied Economics Letters, in press.

Costa-Font, J. and Rovira, J. (2008) 'Who is willing to pay for LTC insurance in Catalonia?', Health Policy 86: $72-84$.

Costa-Font, J., Wittenberg, R., Patxot, C., Comas-Herrera, A., Gori, C., di Maio, A., Pickard, L., Pozzi, A. and Rothgang, H. (2008) 'Projecting long-term care expenditure in four European Union member states: The influence of demographic scenarios', Social Indicators Research 86: 303-321.

Day, C.L. (1993) 'Public opinion toward costs and benefits of social security and medicare', Research on Aging 15: 279-298.

Deeming, C. and Keen, J. (2002) 'Paying for old age: Can people on lower incomes afford domiciliary care costs?' Social Policy and Administration 36: 465-481.

Deeming, C. and Keen, J. (2003) 'A fair deal for care in old age? Public attitudes towards the funding of LTC', Policy and Politics 31: 431-446.

Evandrou, M. and Falkingham, J. (1998) 'The personal social services', in H. Glennester and J. Hills (eds) The State of Welfare: The Economics of Social Spending, Oxford: Oxford University Press.

Ferrer-i-Carbonell, A. (2004) 'Income and well being: An empirical analysis of income effect', Journal of Public Economics 89: 997-1019.

Fong, C. (2001) 'Social preferences, self-interest and the demand for redistribution', Journal of Public Economics 82: 225-246.

Geraedts, M., Heller, G.V. and Harrington, C.A. (2000) 'Germany's LTC insurance: Putting a social insurance model into practice', The Milbank Quarterly 78: 375-401.

Glendinning, C., Davies, B., Pickard, L. and Comas-Herrera, A. (2004) Funding LTC for Older People. Lessons from Other Countries, London: Joseph Rowntree Foundation.

Hall, J. and Preston, I. (1999) 'Tax price effects on attitudes to hypothecated tax increases', Journal of Public Economics 75: 417-438.

Henwood, M. and Waddington, E. (1998) Expecting the Worst: Views on the Future of LTC. A Help the Aged Research Report, Leeds: Nuffield Institute for Health.

Kahneman, D., Knetsch, J.L. and Thaler, R.H. (1991) 'Anomalies: The endowment effect, loss aversion, and status quo bias', Journal of Economic Perspectives 5: 193-206.

Laing, W. (1993) Financing Long Term Care: The Crucial Debate, London: Age Concern.

Lavis, J.N., Ross, S.E., Stoddart, G.L., Hohenadel, J.M., McLeod, C.B. and Evans, R.G. (2003) 'Do Canadian civil servants care about the health of populations?', American Journal of Public Health 93: 658-663.

Layard, R. (2005) Happiness: Lessons from a New Science, London: Allen Lane.

Meltzer, A. and Richard, S. (1981) 'A rational theory of the size of government', Journal of Political Economy 89: 914-927.

Norton, E. (2000) 'Long term care', in A.J. Culyer and J.P. Newhouse (eds) Handbook of Health Economics, Vol. I, Amsterdam: Elsevier Science.

OECD (2004) OECD Social Expenditure Database, Paris: OECD.

Parker, G. and Clarke, H. (1996) Attitudes towards LTC for elderly people: Evidence submitted to the health committee, Nuffield Community Care Studies Unit, University of Leicester, Working Paper No. 38 (January). 
Parker, G. and Clarke, H. (1997) 'Will you still need me? Will you still feed me? Attitudes towards LTC', Social Policy and Administration 31: 119-135.

Parker, G. and Clarke, H. (1998) 'Paying for LTC in the UK: Policy, theory and evidence', in Taylor-Gooby (ed) Choice and Public Policy: The Limits to Welfare Markets, Basingstoke, UK: Palgrave Macmillan.

Preston, I. and Ridge, M. (1995) 'Demand for local public spending: Evidence from the British social attitudes survey', The Economic Journal 105: 644-660.

Rabiner, D.J. (1996) 'Attitudes toward and use of subsequent nursing home services among a national sample of older adults', Journal of Aging and Health 8: 417-443.

Ravallion, M. and Lokshin, M. (2000) 'Who wants to redistribute? The tunnel effect in 1990s Russia', Journal of Public Economics 76: 87-104.

Runciman, W. (1972) Relative Deprivation and Social Justice: A Study of Attitudes to Social Inequality in 20th Century England, Harmondsworth: Penguin.

Strauss, R. and Hughes, D. (1976) 'A new approach to the demand for public goods', Journal of Public Economics 6: 191-204.

Taylor-Gooby, P. (1994) 'Welfare outside the state', in R. Jowell, J. Gurtice, L. Brook and D. Ahrendt (eds) British Social Attitudes Survey: The 11th Report, Aldershot: Dartmouth.

Walker, A. (1999) 'Attitudes to Population Ageing in Europe. University of Sheffield, UK', http:// www.shef.ac.uk/socst/staff/staff_page_elements/a_walker/attitudes.pdf.

Williams, J., Hughes, G. and Blackwell, S. (2006) Attitudes towards Funding of LTC of the Elderly, Dublin: Economic and Social Research Institute.

\section{Appendix}

See Tables A1 and A2.

Table A1 Support for options for LTC responsibility

\begin{tabular}{lllr}
\hline & Family & State & Both \\
\hline Andalusia & 28.68 & 23.53 & 47.79 \\
Aragon & 26.37 & 41.76 & 31.87 \\
Asturias & 40.91 & 19.32 & 39.77 \\
Balearic Island & 22.54 & 36.62 & 40.85 \\
Canary Island & 19.19 & 37.37 & 43.43 \\
Cantabria & 42.65 & 16.18 & 41.18 \\
Castile-Mancha & 28.04 & 21.5 & 50.47 \\
Castile-Leon & 32.86 & 18.57 & 48.57 \\
Catalonia & 21.05 & 45.11 & 33.83 \\
Valencia & 55.43 & 12.5 & 32.07 \\
Extremadura & 26.74 & 19.77 & 53.49 \\
Galicia & 21.17 & 24.09 & 54.74 \\
Madrid & 16.83 & 53.85 & 29.33 \\
Murcia & 15.12 & 18.6 & 66.28 \\
Navarre & 20.9 & 28.36 & 50.75 \\
Basque Country & 31.9 & 29.31 & 38.79 \\
La Rioja & 33.85 & 7.69 & 58.46 \\
Total & & & 42.82 \\
\hline
\end{tabular}

Question: \#19. 
Table A2 Support for option for LTC financing

\begin{tabular}{lccc}
\hline & Soc. insurance & Com. Support & Fiscal relief \\
\hline Andalusia & 88.14 & 9.79 & 2.06 \\
Aragon & 75.34 & 19.18 & 5.48 \\
Asturias & 98.46 & 1.54 & 0 \\
Balearic Island & 91.3 & 8.7 & 0 \\
Canary Island & 71.64 & 25.37 & 2.99 \\
Cantabria & 89.29 & 5.36 & 5.36 \\
Castile-Mancha & 82.93 & 12.2 & 4.88 \\
Castile-Leon & 76.54 & 19.75 & 3.7 \\
Catalonia & 85.44 & 8.25 & 6.31 \\
Valencia & 92.22 & 6.59 & 1.2 \\
Extremadura & 93.33 & 3.33 & 3.33 \\
Galicia & 74.51 & 12.75 & 12.75 \\
Madrid & 77.21 & 16.18 & 6.62 \\
Murcia & 92.31 & 7.69 & 0 \\
Navarre & 89.36 & 8.51 & 2.13 \\
Basque Country & 69.39 & 25.51 & 5.1 \\
La Rioja & 84.62 & 11.54 & 3.85 \\
Total & & & 4.2 \\
\hline
\end{tabular}

Question: \#24.

\section{About the Authors}

Joan Costa-Font is Lecturer in European Social Policy and Political Economy at the London School of Economics and Political Science (LSE). Prior to this he taught economics at the University of Barcelona. He is a research fellow of CESifo (Munich), FEDEA (Madrid), IESE (Barcelona) and CAEPS (Barcelona). His areas of expertise are the political economy of welfare state reform and the economics of social policy, especially health and social care economics.

Anna Garcia-Gonzalez is Research Assistant at CAEPS (Barcelona) and PhD student at the University of Barcelona. Her area of expertise is the economics of social policy. She is completing a PhD on long-term care design (expected in 2009). She has been a visiting research student at the LSE and the University of Amsterdam.

Montserrat Font-Vilalta is Senior Lecturer in Financial Management at the University of Barcelona. She is an expert on the organisation of financial markets and recently she has published widely on issues on the financing of long-term care in the context of Spain and the financial aspect of European integration. 